\title{
RELIGIOUS COURT IN INDONESIA History and Prospect
}

\author{
Idri \\ State Islamic College (STAIN) Pamekasan, Indonesia
}

\begin{abstract}
Since the enactment of Law No. 7 in 1989, religious courts have gained an equal position, in terms of jurisdiction, to other courts in Indonesia, a status that took a considerable time to realize. This article discusses the historical development of religious courts in Indonesia from the early period of Islam in the country to the postindependence period. It particularly highlights internal and external factors which underpin the development of religious courts. Further, this paper examines the development of religious courts under the auspices of the Supreme Court. In the early period of Islam in Indonesia, there was no explicit dichotomy between Islamic and public courts. Religious courts had sole power in the judiciary. During the colonial period, however, the Dutch and Japanese limited the authority of religious courts. After Indonesian independence, the status and authority of religious courts did not change much until the implementation of the Law in 1989.
\end{abstract}

Keywords: Religious court, penghulu, fatwa, $\rightarrow a$ authority.

\section{Introduction}

Islamic courts, better known in Indonesia as "religious courts" have, experienced a rollercoaster development since the early days of Islam in Indonesia. As a result of the needs of the Muslim community for a juridical-formal institution based on Islamic law, religious courts have, over the years, developed and evolved, through frequent innovation and improvement. From a historical point of view, religious courts have experienced many ups and downs; from the very beginning of Islam in Indonesia, through the period of Islamic kingdoms, the Dutch and Japanese colonial period, and the 
independence period. In every period, the socio-political constellation had a marked influence on this institution.

Throughout this long history, this institution, which today enjoys equal legal recognition to the rest of the judicial bodies in Indonesia, has undergone many changes in its authority, position, and basic nature. These changes have essentially been due to differences in legal policy from one period to another period. Especially during the colonial period until the time of independence, certain barriers had a significant bearing on its journey. However, Indonesian independence did not immediately restore the institution as an established and independent body. That did not happen until 1989, when a fresh wind blew through the system, and a legal framework was enacted to rejuvenate this institution under Law No. 7 of 1989 on religious court judicial authority.

\section{The Development of Religious Courts in Indonesia}

\section{During The Islamic Kingdom Period}

Soon after Islam came to the archipelago, Islamic law came into force. ${ }^{1}$ Thus the existence of Islamic law has long been a feature in public life. Besides the pure religious rituals (ibath mahth in practical life, Islamic law of marriage (figh al-munathos was soon observed. This law relating to family issues had been applied in the community because according to Islamic teachings, a Muslim must arrange an Islamic marriage. Otherwise, his or her un-Islamic marriage would be considered null, and any sexual intercourse in such marriages would be considered adultery or fornication, a major sin in Islam. In addition, according to Islamic Law, a Muslim can not marry a nonMuslim woman. Therefore, when a Muslim merchant married a local woman, the first thing he had to do was to ask her to convert to Islam, then the marriage ceremony was held in accordance with that religion. ${ }^{2}$ Along with the growing Muslim population, Islamic law also extended to various other human activities that, in one way or another, also bore a significant influence of local traditions.

1 Daud Ali, Kedudukan Hukum Islam dalam Sistem Hukum Indonesia (Jakarta: Yayasan Risalah, 1984), p. 7.

2 Ibid., p. 29. 
When there were disputes between early Indonesian Muslims, a settlement was achieved in one of three ways. First, in the early days, when the Islamic kingdoms had not been established yet and Muslim population was marginal in number, the disputes were solved by seeking a fatwa from a local Muslim jurist. At that time, there was no formal power to implement the decisions of that fatwa $>$ The only binding power was the belief that both litigant parties complied with that decision. Generally, the fatwa $>$ was about cases of civil law,

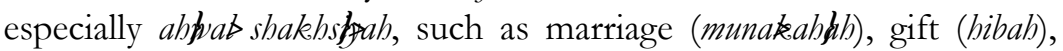
inheritance (mawru), and so forth, and not related to the

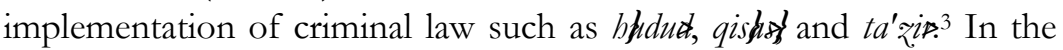
early period, the procedures taken included two possibilities: first, the litigants submitted the cases of law to a jurist and then he made a decision in accordance with the provision of Islamic law; and second, person(s) other than litigants raised the case to an ulama (Islamic scholar), then he formed a decision even though the litigant parties did not submit the case. This second possibility happen because the Muslim community at that time was still small and Islamic scholars mostly served themselves as preachers.

As the Muslim community grew (but still not yet realized the political power of a kingdom), cases which occurred were decided collectively by a court of traditional leaders, consisting of elders, ulama, community leaders, and/or ninik-mamak as arbitrators or qasuch courts were already in existence in Hindu times, long before the Islamic period. However, in the Islamic courts the assembly of judges decided cases in accordance with Islamic law and they were appointed based on consensus at the meeting of population according to local mores. ${ }^{4}$ Unlike the early period, this time legal determinations and decisions were more binding because they were reached through established traditional institutions.

With the formation of Islamic kingdoms, a third development occurred, Kings appointed jurists who were considered as competent

3 Authors Team of Direktorat Pembinaan Badan Peradilan Agama Islam, KenangKenangan Seabad Peradilan Agama di Indonesia (Jakarta: Dirjen Binbaga Depag RI, 1985), p. 8.

4 Zaini Ahamad Noeh, "Waliyul Amri Addaruri Bisy Syaukah, Antara Fakta Historis dan Politik," Panji Masyarakat, No. 456, (January 2, 1985), pp. 63-64. 
to be judges or qa to solve problems that occurred in their regions. ${ }^{5}$ During this period, Islamic law attained a prominent position in society, and could even be considered the official state law. ${ }^{6}$ In the kingdom of Mataram (Java), for example, kyai penghulu (Islamic leaders) were appointed by the king to take care of issues relating to religion

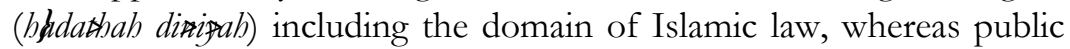
administration was left to the pepatih dalem. The king, kyai penghulu, and pepatih dalem, in the governmental system of Mataram acted as a triumvirate, controlling and running the royal government. ${ }^{7}$ This division of power, however, was not identical to the legislative, executive, and judiciary separation of powers in the theory of Montesquieu's 'Trias Politica'. In the kingdom of Mataram, the three powers were basically in the hands of the king (monarchy), while the kyai penghulu (headman) and the pepatib served as the king vicegerents.

Thus, the authority of religious matters in the kingdoms rested in the hands of the penghulu. When the kingdom of Demak was in power, the position of penghulu was handed over to Sunan Kudus and Sunan Kalijaga. In the kingdom of Pajang, the authority was represented by Penghulu Kudusulngalam I to V and in Surakarta by Tapsir Anom I to VI. ${ }^{8}$ In this last kingdom mentioned, the penghulu had at least four responsibilities: namely to lead worship, such as Friday prayers and congregational prayers; to deliver decisions on cases of judicial duty such as divorce, inheritance, wills, husband-wife disputes, and gana-gini (inherited wealth); to guide people in religious life, including religious education; and to perform the duties of marriage guardian (for women with no guardian) and to establish a marriage covenant. ${ }^{9}$

Religious courts at that time varied from one kingdom to another. This variation was seen in several areas. First, diversity was very

5 Authors Team of Direktorat Pembinaan Badan Peradilan Agama Islam, KenangKenangan, p. 9.

${ }^{6}$ Ahmad Rafiq, Hukum Islam di Indonesia (Jakarta: PT. Raja Grafindo Persada, 1995), p. 12.

7 Zaini Ahamad Noeh, Sebuah Perspektif Sejarah Lembaga Islam di Indonesia (Bandung: PT. Al-Maarif, 1980), p. 44.

${ }^{8}$ Deliar Noer, Administrasi Islam di Indonesia (Jakarta: CV. Rajawali Press, 1996), p. 16.

${ }^{9}$ See in Soemarsaid Moertono, Negara di Jawa Masa Lampau; Studi tentang Masa Mataram II (Jakarta: Yayasan Obor Indonesia, 1985 ), p. 98. 
dependent on how the Islamization process was conducted by religious officials and scholars in general, and on the forms of integration between Islamic law and local customs that had evolved before the arrival of Islam. A second cause of this diversity in religious courts lay in the autonomy and unique environments of the respective kingdoms. Third, variation was seen in the hierarchy of courts and their authority to perform functions in relation to the power of the government in general, and also the source of accepted law-making authority. Those various factors were related to elements of local tradition and the Islamization process which was still in its early phase, as well as the judiciary's position in the organizational structure of different kingdoms. In some kingdoms it received less attention, whereas in others it was a central institution.

During the time of Sultan Agung of Mataram (1613-1645), the leadership of the courts, even though principally in the hands of the sultan, moved to the penghulu (headman), who was assisted by several Muslim scholars from various Islamic schools as members of the board. When Amangkurat I succeeded Sultan Agung in 1645, the civil court, active during the Hindu period, was reinstalled to reduce the influence of ulama in the courts, and the king himself held the reins of leadership. In this way features of the court as implemented at the time of Sultan Agung continued into the Dutch colonial period.

The variation in the appearance of Mataram's religious court did not only rest in the court order and its hierarchy, but also in institutions and law-making sources. Therefore, it can be said that the interaction between various factors affected the nature of the religious courts in the Islamic kingdoms, although in the case of Sultan Agung and Amangkurat I, they were the most authoritative figures in dictating the course of the court.

When we consider numbers, in Banten there was only one religious court, led by qa a single judge. In contrast, there were several judges besides penghulu judges in the period of Sultan Agung of Mataram, whereas the religious courts of Cirebon were carried out by seven ministers, represented by three authorities; the Sultan Sepuh, Sultan Anom, and Panembahan of Cirebon. In this Cirebon royal court, all cases tried by the ministers were decided according to Papakem, a 
book that was highly influenced by Islamic law. ${ }^{10}$ Of the three courts, seen from the composition of judges in handling legal matters, the Banten court was the simplest.

Unlike the judicial system in Java, the religious courts in Aceh were conducted on various levels. The first level court operated on the village level, and was led by an arbitrator called keucik. This court handled only petty cases; more severe cases were heard by the Mukim or Law Center. When one of the litigant parties was not satisfied with the decision of the first level, he or she might lodge an appeal to the Uleebalangs (second-level courts). A further appeal might be submitted to the Panglima Sagi. If still not satisfied, then he or she might continue the appeal to the Sultan. It would be heard by the Supreme Court made up of; Malikul Adil, The Rich Sri Master, the Rich King Bandhara, and Fakih (Ulama). ${ }^{11}$

In some places, such as South and East Kalimantan, religious judges were appointed by local authorities. In other regions, such as North Sulawesi and South Sumatera, there was no special appointment to assume judgeship position. In these areas, religious leaders directly performed judicial duties automatically. ${ }^{12}$ The implementation of religious courts in some regions also varied, when viewed from the perspective of hierarchy, authority, and delegation.

In the early days of Islam in the archipelago and the period of Islamic kingdoms, Islamic law was fully applicable among Muslims. L.W.C. Van Den Breg, in his theory, Receptio in Complexu, states that Islamic law was fully accepted by Muslims from the period of Islamic kingdoms until the beginning of the VOC's presence in the archipelago. The Dutch were told not to interfere with all applicable legal matters in society. ${ }^{13}$

\footnotetext{
${ }^{10}$ Ibid., p. 108.

11 Ibid.

12 Daniel S. Lev, Islamic Courts in Indonesia; A Study in the Political Bases of Legal Institutions (Los Angeles: University of California Press, 1972), p. 10.

${ }^{13}$ Rahmat Djatmika, "Sosialisasi Hukum Islam di Indonesia," in Abdurrahman Wahid et. al., Kontroversi Pemikiran Islam di Indonesia (Bandung: Remaja Rosdakarya, 1991), pp. 231-232.
} 


\section{During The Dutch and Japanese Colonial Period}

\section{The Dutch Colonial Period}

Becoming increasingly strong in Indonesia, the Dutch East India Company on May 25, 1760 AD issued a formal decree of Resolutio der Indischr Regeering, known as Compendium Freijer. These rules strengthened the implementation of Islamic family law (marriage and inheritance), but they replaced the authority of Islamic religious institutions formed by the Muslim kings or the sultans with new courts established by the Netherlands. ${ }^{14}$ The existence of Islamic law ${ }^{15}$ in Indonesia was then fully recognized by the Dutch after the revocation of Compendium Freijer gradually and finally with Staatstablaad No. 354 year 1913.16

With regard to judicial institutions, during the Dutch colonial period these varied. According to Supomo, there were five judicial orders at that time: first, gubernemen courts in all territories of Netherlands East Indies Company; second, the indigenous (pribumi) courts in Java and Madura, and in Aceh residency, Tapanuli, West Sumatra, Jambi, Palembang, Bengkulu, Riau, West Kalimantan, South Kalimantan and East Java, Manado, Sulawesi, Maluku, and the Lombok residency of Bali and Lombok island; third, self-government (swapraja) courts in almost all areas except the autonomous Pakualam and Pontianak; fourth, the religious courts in the areas where the gubernemen judicial existed or in the areas that were part of the native court, or in the autonomous regions that were part of judicial selfgovernment; and fifth, village courts scattered in areas where the gubernemen judicial existed. In addition, there were also village courts,

14 M. Daud Ali, Kedudukan Hukum Islam dan Sistem Hukum di Indonesia (Jakarta: Risalah, 1984), p. 12.

15 At that time, Islamic law was recognized as legal authority, however, its existence and shape was similar to the unwritten customary law as appropriate laws and regulations. And there were only the books of fiqh that still shaped the study of Islamic jurisprudence in a variety of schools, although the majority are Shat See Abdurrahman, Kompilasi Hukum Islam di Indonesia (Jakarta: Akademika Pressindo, 1995), pp. 15-29.

16 Munawir Sjadzali, "Landasan Pemikiran Politik Hukum di Indonesia dalam Rangka Menentukan Peradilan Agama di Indonesia," in Tjua Suryaman, Politik Hukum di Indonesia, Perkembangan dan Pembentukannya (Bandung: Remaja Rosdakarya, 1991), pp. 43-44. 
which was a part of the indigenous justice and judicial selfgovernment. ${ }^{17}$

The attitude of the Dutch colonial authority toward the five courts was different. Gubernemen courts were prioritized more than other courts, including the religious courts. At first, the Dutch did not interfere with the administration of religious courts. Their intervention in religious courts occurred for the first time in 1820.18 At that time, the Dutch colonial authority instructed all Regents in Java and Madura to order Islamic jurists to quickly resolve disputes over inheritance. ${ }^{19}$ At this stage, known as Regerenten Instruktie, ${ }^{20}$ they did not yet control the courts, at least in terms of determining the course of "Islamic courts", because they did not desire to possess that control. Moreover, Dutch legal experts such as Mr. Schoulten, Van Oud Haarlem, Carel Frederick Winter, and Solomon Keyzer advised the government to leave religious courts as they were, without any supervision and scrutinization form the authorities.

The above account paints a picture of the course of religious courts in the early stages of the Dutch colonial period. In this period, the religious courts, which still had not been recognized (established) officially by the Dutch, still operated as they did prior the Dutch. Then, in 1882, with the issuance of Stbl. No. 152, year 1882, the religious court (Priesterrad) was officially formed. With this decision of the Dutch king, dated August 1 1882, the Dutch government officially acknowledged the existence of this institution in the Dutch East Indies. ${ }^{21}$ However, even though a religious court had been officially established, in reality, the Dutch government did not enforce it like the general courts (District Council). They did not provide budgets and salaries for the staff who worked in the religious court except the head of the court alone, and this was only because of his position as adviser

17 R. Soepomo, Sistem Hukum di Indonesia Sebelum Perang Dunia II (Jakarta: Pradnya Paramita, 1970), p. 20.

18 Zaini Ahmad Noeh and A. Basit Adnan, Sejarah Singkeat Pengadilan Agama di Indonesia (Surabaya: Bina Ilmu, 1983), p. 31.

${ }^{19}$ Ibid.

${ }^{20}$ Ibid.

21 Authors Team of Direktorat Pembinaan Badan Peradilan Agama Islam, KenangKenangan, p. 9. 
to the general court. All costs required were taken from the cost of the cases. In addition to cost issues, at the initial recognition, all religious court decisions had to request an executoire Verklaring (statement of execution from the district/public courts). Thus, in effect, there was a double judicial process resulting in increasing costs. ${ }^{22}$

The Dutch attitude was clearly detrimental to Muslims; with the executoire Verklaring, the position of religious courts became weaker because any decision could only be executed when confirmed or approved by the public court judges. This was different from the previous period, when religious courts assumed full authority to decide cases and execute them. For the litigants, settlement expenses increased. Similarly, the unavailability of budgets and salaries for the staff of religious courts was a major challenge. One thing that should be considered is the reason for such a policy by the Dutch. It seems the major reason might be their desire to circumvent religious courts, leading Muslims to bring their cases to public courts.

When Snouck Hurgronje was appointed as an advisor to indigenous affairs in the Dutch East Indies, supervision through executoire Verklaring was eliminated. Hurgronje opposed the Dutch government's decision stipulated in Stbl. No. 152 year 1882. He believed that the Dutch East Indies policy to recog nize and hold religious courts in addition to the public court was a regrettable mistake. The development of Islamic law should be left without any official recognition from the general judicial officers. ${ }^{23}$

Hurgronje's attitude did not mean giving the opportunity to Muslims to independently resolve their cases in religious courts. On the contrary, with the development of the theory of receptie, a rejection of, Van den Berg's theory of receptie in complexu, that Islamic law was applicable law to the indigenous people, Hurgronje's opinion threatened the very existence and authority of religious courts. According to the receptie theory, a new Islamic law could only be enforced when it was received or become customary law. ${ }^{24}$ Hurgronje's

22 Daud Ali, "Kedudukan Hukum Islam dalam Sistem Hukum Indonesia," in Taufik Abdullah (ed.), Tradisi Kebangkitan Islam di Asia Tenggara (Jakarta: LP3ES, 1988), p. 221.

23 Daud Ali, Teori Receptie dalam Pemikiran Hukum Indonesia, Paper on upgrading Lecturers of Religious Affairs (Jakarta, Januari 1992), p. 4.

${ }^{24}$ Sayuti Thalib, Receptio A contrario (Jakarta: Bina Aksara, 1985), p. 13. 
theory was based on his research in Aceh and other areas. He concluded that applicable laws in different regions of the Dutch East Indies did not include Islamic law. Islamic law was effective only if it was accepted by local customary laws. ${ }^{25}$ Hurgronje said that Indonesian Muslims were more respectful to mystical aspects of Islam than its legal aspects. They were more appreciative of speculative religious ideas than the implementation of the obligations of their religion into real life. At this time, Islam was still mixed with the remnants of the Indian Hindu-Buddha heritage. Therefore, unlike Islamic law, mysticism had a significant influence on all of the population. ${ }^{26}$

The theory of receptie proposed by Hurgronje influenced the existence of religious courts in Indonesia to a considerable extent. Based on this theory, the Dutch Government began a review of legislation on the implementation of Islamic law in the Dutch East Indies. In 1922, they established a commission in charge of reviewing the authority of religious courts that had been officially recognized since 1882. This commission, chaired by Ter Haar, suggested the Dutch authority limit judicial authority to the aspects of religion in which Islamic law was already accepted by customary law. ${ }^{27}$ Since only Islamic marriage law was considered to have been received as part of local customary law, the judicial authority of religious court was thus limited to laws of marriage, and did not include cases of inheritance, waqf (endowments), bibah (grants), hadanah (child guardianship), and property. With the enactment of Stbl. 1937 No. 116, judicial authority was limited to marriage law, and only applied to the areas of Java and Madura. ${ }^{28}$ Meanwhile, in April 1, 1937, inheritance cases were shifted from the authority of religious courts to state courts, which examined cases based on customary inheritance. ${ }^{29}$ With the issuance of

\footnotetext{
${ }^{25}$ Ali, Teori Receptie, p. 4.

26 Snouck Hurgronje, Kumpulan Karangan Snouck Hurgronje, Volume X (Jakarta: INIS, 1994), pp. 24-25.

27 Thalib, Receptio, p. 19.

28 Authors Team of Direktorat Pembinaan Badan Peradilan Agama Islam, KenangKenangan, p. 22.

${ }^{29}$ Habibah Daud, Perubahan Pengadilan Agama dalam Penyelenggaraan Masalab Kewarisan di Indonesia (Jakarta: Directorate of Religious Affairs Justice Board Republic of Indonesia, 1982), p. 42.
} 
regulations that limited the authority of religious courts, the position of the head of religious courts as an advisor to the district court was also automatically revoked, since it was no longer required by the Dutch East Indies government. 30

The enactment of Stbl.1937 had a negative impact on the existence of religious courts. Still, it also led to positive developments. Stbl. 1937 No. 610 and Stbl. 1937 No. 638. Stbl. 1937 No. 610 formed the legal basis for the establishment of the Higher Islamic Court (Mabkamah Islam Tinggi) of appeal in the areas of Java and Madura. The authority of the Higher Islamic Courts comprised the following responsibilities: first, to hear disputes on matters requested by relevant appeals decided by lower religious courts; and second, to provide advice in matters of Islam when requested by the Governor-General or other state authorities. Further, Stbl. 1937 No.638 was the basis for the establishment of religious courts in South and East Kalimantan. The first level it was called the Qa ssembly (Kerapatan Qadi), while the appeals court was called the Great Qa Besar). ${ }^{31}$ The authority of the Qa sembly resembled the authority of Religious Courts and the authoritys of the Great Qassembly was similar to that of the Higher Islamic Court in Java and Madura.

Detailed records of the religious courts in Java and Madura included the following cases: [1] a dispute between Muslim husbands and wives, [2] the cases of marriage, divorce, and reconciliation among Muslims, [3] implementation of divorce, [4] marriage contract in relation to divorce (ta lipal-tallał, [5] mahr or dowry cases, and [6] cases of the financial obligations of husband for his wife (nafaqab). ${ }^{32}$

It can be said that the authority of religious courts during the Dutch colonial period was very narrow since, in practice, they were limited to family matters (abuza $\rightarrow$ hakhsizab), and did not hear other civil cases, let alone criminal offences. This restriction was understandable because the Dutch colonial authority did not support the formal imposition of Islamic law except in the area of family law, particularly marriage and inheritance.

\footnotetext{
${ }^{30}$ Ibid.

31 Ibid.

32 Bisri, Peradilan Agama, p. 113.
} 


\section{Japanese Occupation Period}

At the time of Japanese occupation in Indonesia (1942-1945) a rule of transition, in the form of Law No. 1 Year 1942, was issued. In Chapter 3 it stipulated that, for all agencies of government, laws and the regulations of the previous government would still be recognized as valid as long as they did not conflict with the regulations of the Japanese military authority. To control courts, the Japanese authority issued Law No. 14 of 1942, which regulated the military court of Dai Nippon (Gunsei Hooin). This court, as mentioned in Article 3 of Law, consisted of six judicial agencies; State Courts (Tibo Hooin), Police Courts (Keiza Hooin), District Courts (Ken Hooin), Representative Courts (Gun Hooin), Islamic Higher Courts (Koyo Kai Kooto Hooin), and Religious Courts (Sooryo Hooin). 33

Japanese intervention in religious courts was quite modest, allowing a recovery in the power of religious courts regarding inheritance and endowment cases through Sanyo Kaigi (Advisory Council). This restoration was carried out by Islamic groups, but opposed by nationalist groups. This conflict between Islamic and nationalist groups generally mirrored the relationship between religion and state, which originated from the political and cultural background of each group. On one hand, the Islamic group wanted the establishment of an Islamic state; on the other hand, nationalist groups wanted a secular state. ${ }^{34}$

Competition between the two groups was reflected in the perspectives of two nationalist and Islamic leaders in the House of Sanyo; Abikusno and Supomo. Abikusno, from the Muslim parties, believed that religious courts should be preserved and their authority in the field of inheritance restored. In addition, religious courts should be strengthened by well-educated staff and salaried by the government. In contrast, the nationalist Supomo argued that the secular state must be modern and not based on Islam. 'If the "Islamic court" could not be abolished, the archangel position in civilian agencies should be abolished'. ${ }^{35}$ The debates between these compatriots during the

33 Authors Team of Direktorat Pembinaan Badan Peradilan Agama Islam, KenangKenangan, p. 24.

34 Bisri, Peradilan Agama, p. 115.

${ }^{35}$ Lev, Islamic Courts, p. 37. 
Japanese period, not caused by the policy of Japanese occupation authority, stalled the restoration and improvement of religious courts. As a result, in that period of Indonesian history, religious courts were still under ascendancy of state courts and continued so until Indonesia gained independence.

\section{After Independence}

Soon after the declaration of Indonesian independence in 1945, despite a de facto transfer of authority, there was no radical change in the judicial system, especially religious courts. This was because the Indonesian people were instantly forced to defend their new independent state from the returning Dutch. In addition, the constitutional framework upon which the administration bodies of state power would be reformed, was not yet decreed.

At the beginning of independence, religious courts were under the Ministry of Justice. Then, once the Ministry of Religious Affairs was established on January 3, 1946, religious courts and religious higher courts, were transferred to the Ministry of Religious Affairs according to Government Decree No. 5/SD of May 15, 1946. From then on, the Ministry of Religious Affairs became responsible for the restoration and improvement of religious courts based on practices during preindependence era. ${ }^{36}$

In the next period, based upon Article 98 of the Temporary Constitution (Undang-Undang Dasar Sementara) and Article 1 paragraph (4) Emergency Constitution (Undang-Undang Darurat) No. 1 Year 1951, the government issued Regulation No. 45, 1957 to establish religious courts outside Java and Madura, South and East Kalimantan. The authority of religious courts included the settlement of marriage (marriage, divorce, and reconciliation), inheritance, hadanah, endowments, grants, and charity. ${ }^{37}$ From then on, religious courts were established and found in virtually all regions of Indonesia. In addition, some indigenous courts (pengadilan pribumi) in various regions were transformed into religious courts. Nonetheless, such a policy was not followed up by technical and administrative regulating frameworks.

\footnotetext{
36 Abdul Mannan, "Peradilan Agama dan Tata Peradilan Negara Indonesia" (Paper presented to the conference "Orientasi Kompilasi Hukum Islam", Bengkulu, July 1997), p. 21.

${ }^{37}$ Ibid.
} 
As a result of this situation although they were somewhat similar to each other, great diversity was found among the courts in terms of legal basis, status, composition, and authority during the period of Old Order regime. Only after 1970, with the enactment of Law No.14, 1970 on judicial powers and Law No. 1, 1974 on marriage, did religious courts experience significant change. With the enactment of Law No.14, 1970, the position of this institution as one of the judicial powers became clearer. With the enactment of this law, the power of religious courts was defined further. Law No. 14, 1970 was then enhanced by the Ministry of Religious Affairs Decree No. 6, 1980, which equated the names of the courts with the title "Religious Court" for the first level and "Higher Religious Court" for the appeals level. ${ }^{38}$

The position of religious courts was further elevated with Law No. 7, 1989 on Religious Courts. Formerly, the authority of religious courts was somewhat weak because all decisions made by a religious court had to be endorsed by state or public courts. With the application of this law, such an endorsement was no longer necessary, elevating the position of religious courts to that of other courts. ${ }^{39}$ Predictably, it has had enormous consequences, not only due to its judicial aspects but also the 'well-being of the judges'. All decisions generated by religious courts can be executed without having been confirmed by the state or public courts and the salaries of their judges are identical with those of other courts judges.

Thus, in carrying out their duties, religious courts are autonomous and independent. All legal products of these institutions are legally binding, equivalent to the products of other judicial institutions. Furthermore, with the enactment of Law No. 3, 2006 which abolished Law No. 7, 1989, the authority of the religious courts now includes the inspection, resolution, and settlement of cases at the first level of judiciary for Muslim people in the area of marriage, inheritance, wills, grants, endowments, charity, infas, sddaqah; and shari $>b$ economic transactions. The new authority of the courts is shariah economic transactions. The shari $>$ ab economic transactions includes: shari $>b$

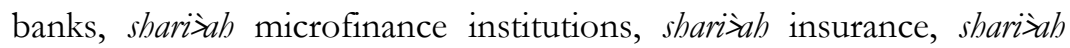
reinsurance, shari $>h$ mutual funds, shari $>h$ bonds and shari $>h$ securities

\footnotetext{
38 Ali, Kedudukan Hukum Islam, pp. 252-253.

${ }^{39}$ Bisri, Peradilan Agama, pp. 119-120.
} 


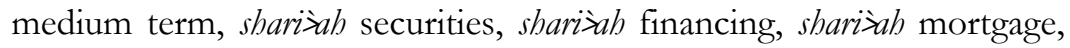
and shari $>h$ business.

\section{The Prospect for Religious Courts in Indonesia}

The development of religious courts in the future depends on their human resources. These institutions are also highly dependent on other internal factors, namely training for the judiciary, organization, administration, finances, as well as external factors, such as judicial services for stakeholders or users.

Religious courts can take steps towards their strategic improvement by prioritizing the following areas: first, improving human resources in religious courts as well as their administrative elements; second, public relations campaigns relating to their authority as stipulated in the Law No. 7, 1989; third, managing and controlling administrative costs; 40 and fourth, fostering public trust in the existence of religious courts, particularly in terms of their ability to resolve cases quickly, inexpensively, cleanly, and justly.

With such measures, religious courts in Indonesia can, in future, not only enjoy an equal position to other courts at the formal-judicial level as happens today, but they may also provide professional, transparent, accountable services to litigants and be at the forefront of judicial reform in Indonesia.

\section{Conclusion}

In the early period of Islam and before the establishment of the Islamic kingdoms, religious courts were ill-defined in terms of form, authority, and responsibility. This is because at that time no formal institutions had been established by the government or empires. During the period of the Islamic kingdoms, religious courts were diverse in terms of autonomy, structure and hierarchy, and their power in relation to the power of the royal governments.

When the Dutch colonized Indonesia, considerable variety in religious courts persisted, but the authority of such courts was degraded as the colonial authority put more emphasis on the civil judiciary. This degradation was caused by the Dutch colonial authority's rejection of the presence of "Islamic courts" in the system of colonial judicial power. The enactment of executoire verklaring (by

${ }^{40}$ Ibid., pp. 246-247. 
which religious court decisions had to be confirmed by state/public courts) was a definite hindrance to the development and independence of these Islamic institutions, which continued until the period of independence and only ended in 1989. At the time of independence, religious courts continued to face obstacles but gradually gained a foothold, especially after the shift of judicial administration from the Ministry of Religious Affairs to the Supreme Court. Moreover, the authority to hear cases concerning Islamic economic transactions, although it is not an easy responsibility, has elevated religious courts to an unprecedented position in post-independence Indonesia.[]

\section{Bibliography}

\section{Books and Articles}

Abdullah, Taufik (ed.). Tradisi Kebangkitan Islam di Asia Tenggara. Jakarta: LP3ES, 1988.

Abdurrahman. Kompilasi Hukum Islam di Indonesia. Jakarta: Akademika Pressindo, 1995.

Ali, Daud. Kedudukan Hukum Islam dalam Sistem Hukum Indonesia. Jakarta: Yayasan Risalah, 1984.

------. Teori Receptie dalam Pemikiran Hukum Indonesia. Paper on upgrading Lecturers of Religious Affairs, Jakarta, Januari 1992.

Authors Team of Direktorat Pembinaan Badan Peradilan Agama Islam. Kenang-Kenangan Seabad Peradilan Agama di Indonesia. Jakarta: Dirjen Binbaga Depag RI, 1985.

Basri, Cik Hasan. Peradilan Agama di Indonesia. Jakarta: CV. Rajawali Persada, 1996.

Daud, Habibah. Perubahan Pengadilan Agama dalam Penyelenggaraan Masalah Kewarisan di Indonesia. Jakarta: Direktorat Badan Peradilan Agama RI, 1982.

Hurgronje, Snouck. Kumpulan Karangan Snouck Hurgronje. Jakarta: INIS, 1994.

Lev, Daniel. Islamic Courts in Indonesia, A Study in the Political Bases of Legal Institutions. Los Angeles: University of California Press, 1972. 
Mannan, Abdul. "Peradilan Agama dan Tata Peradilan Negara Indonesia." Paper presented to the conference "Orientasi Kompilasi Hukum Islam”, Bengkulu, July 1997.

Moertono, Soemarsaid. Negara di Jawa Masa Lampau, Studi tentang Masa Mataram II. Jakarta: Yayasan Obor Indonesia, 1985.

Noer, Deliar. Administrasi Islam di Indonesia. Jakarta: CV. Rajawali Press, 1996.

Noeh, Zaini Ahmad dan A. Basit Adnan. Sejarah Singkat Pengadilan Agama di Indonesia. Surabaya: Bina Ilmu, 1983.

Noeh, Zaini Ahamad. Sebuah Perspektif Sejarah Lembaga Islam di Indonesia. Bandung: PT. Al-Maarif, 1980.

-------. Waliyul Amri Addaruri Bisy syaukah, Antara Fakta Historis dan Politik. Jakarta: Panji Masyarakat, No. 456, 2 Januari 1985

Rafiq, Ahmad. Hukum Islam di Indonesia. Jakarta: PT. Raja Grafindo Persada, 1995.

Sjadzali, Munawir. "Landasan Pemikiran Politik Hukum di Indonesia dalam Rangka Menentukan Peradilan Agama di Indonesia." in Tjua Suryaman. Politik Hukum di Indonesia, Perkembangan dan Pembentukannya. Bandung: Remaja Rosdakarya, 1991.

Soepomo, R. Sistem Hukum di Indonesia Sebelum Perang Dunia II. Jakarta: Pradnya Paramita, 1970.

Thalib, Sayuti. Receptio A contrario. Jakarta: Bina Aksara, 1985.

Wahid, Abdurrahman et. al. Kontroversi Pemikiran Islam di Indonesia. Bandung: Remaja Rosdakarya, 1991. 